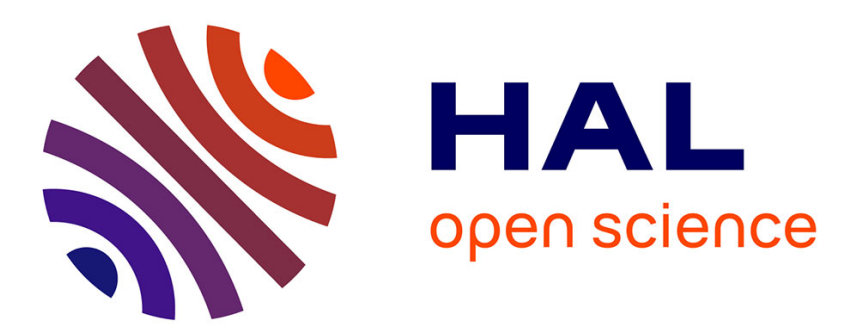

\title{
Inhibition of calcium-dependent motility of cochlear outer hair cells by the protein kinase inhibitor, ML-9
}

Donald E Coling, Sylvain Bartolami, Douglas Rhee, Torben Neelands

\section{To cite this version:}

Donald E Coling, Sylvain Bartolami, Douglas Rhee, Torben Neelands. Inhibition of calcium-dependent motility of cochlear outer hair cells by the protein kinase inhibitor, ML-9. Hearing Research, 1998, 10.1016/S0378-5955(97)00194-9 . hal-02156380

\section{HAL Id: hal-02156380 \\ https://hal.science/hal-02156380}

Submitted on 18 Jun 2019

HAL is a multi-disciplinary open access archive for the deposit and dissemination of scientific research documents, whether they are published or not. The documents may come from teaching and research institutions in France or abroad, or from public or private research centers.
L'archive ouverte pluridisciplinaire HAL, est destinée au dépôt et à la diffusion de documents scientifiques de niveau recherche, publiés ou non, émanant des établissements d'enseignement et de recherche français ou étrangers, des laboratoires publics ou privés. 


\title{
Inhibition of calcium-dependent motility of cochlear outer hair cells by the protein kinase inhibitor, ML-9
}

\author{
Donald E. Coling ${ }^{\mathrm{a}, *}$, Sylvain Bartolami ${ }^{\mathrm{b}}$, Douglas Rhee ${ }^{\mathrm{a}}$, Torben Neelands ${ }^{\mathrm{a}}$ \\ ${ }^{a}$ Kresge Hearing Research Institute, University of Michigan, 1301 E Ann St, Ann Arbor, MI 48109-0506, USA \\ b Laboratoire de Neurophysiologie Sensorielle, Université Montpellier II, Place Eugène Bataillon, 34095 Montpellier, France
}

Received 25 February 1997; revised 30 August 1997; accepted 16 October 1997

\begin{abstract}
The calcium ionophore ionomycin has been shown to induce length increases of guinea pig outer hair cells (Dulon et al., 1990). We have demonstrated that these length increases can be inhibited by a 30 min preincubation of the cells with the protein kinase inhibitor ML-9. At either 30 or $60 \mathrm{~s}$ after ionomycin application, the effect of ML-9 was dose-dependent with a half maximal response at approximately $0.3 \mu \mathrm{M}$. No effect on cell length was detected after 30 min incubation with 0.5 and $5 \mu \mathrm{M}$ ML-9 alone. However, with 50 and $500 \mu \mathrm{M}$ ML-9, significant contraction in cell length was observed. $50 \mu \mathrm{M}$ ML-9 did not interfere with the ability of ionomycin to elevate fluorescence of the calcium indicator Fluo-3, nor did it alter the ability of cells to exclude propidium iodide from their nuclei. Treatment with $500 \mu \mathrm{M}$ ML-9 resulted in impaired cell morphology. The data support the hypothesis that protein kinase activity regulates calcium-dependent processes that effect shape changes of outer hair cells. They are consistent with the involvement of the calcium/calmodulin-dependent enzyme, myosin light chain kinase, a known target of ML-9, but do not preclude the possibility of another intracellular target for ML-9. (C) 1998 Published by Elsevier Science B.V. All rights reserved
\end{abstract}

Key words: Outer hair cells; Sensory receptor cells; Calcium; Calmodulin; Protein kinase; Motility; ML-9

\section{Introduction}

Outer hair cells from the mammalian cochlea are reciprocal transducers. Like inner hair cells and receptor cells for other sensory modalities, outer hair cells convert energy from sensory signals into electrical energy in the form of a receptor potential (Dallos, 1985; Köessl and Russell, 1992; Preyer et al., 1996) in what has come to be known as 'forward transduction'. Unlike other sensory receptors, they are capable of operating in a 'reverse transduction' mode whereby electrical energy is converted into mechanical displacement of the cell body (Brownell et al., 1985; Kachar et al., 1986; Zenner, 1986; Ashmore, 1987). Electromotility of outer hair cells, also known as 'fast motility', is currently thought to provide a system of mechanical feedback,

\footnotetext{
* Corresponding author. Present address: Department of Molecular and Cell Biology, University of California, Berkeley, Life Sciences Addition, Berkeley, CA 94720, USA. Tel.: +1 (510) 642-4360; Fax: +1 (510) 643-6791; E-mail: fortelab@lsa.berkeley.edu
}

the so called cochlear amplifier (Davis, 1983), that sharpens the ability of the inner ear to discriminate acoustic stimuli (reviewed in Dallos, 1992; Holley, 1996).

Several conditions have been investigated that involve length changes of outer hair cells with rates much slower than those described for electromotility, but driven by internal forces of comparable magnitude (Goldstein and Mizukoshi, 1967; Zenner et al., 1985; Flock et al., 1986). 'Slow motility' responses can be elicited in response to osmotic forces (Zenner et al., 1985; Dulon et al., 1987) and to a variety of chemical stimuli (Zenner et al., 1985; Flock et al., 1986; Schacht and Zenner, 1987; Ulfendahl, 1987; Dulon et al., 1990).

One stimulation with potential physiological significance is elevation of intracellular calcium. Calcium and ATP induce slow, longitudinal contractions when applied to permeabilized cells (Flock et al., 1986; Schacht and Zenner, 1987; Ulfendahl, 1987) and when injected (Dulon et al., 1988). In intact (nonpermeabilized) cell 
models, elevation of intracellular calcium results in longitudinal elongation. This effect can be obtained using ionophores (Dulon et al., 1990) or simply by raising extracellular calcium (Pou et al., 1991). Although calcium has an opposite effect on cell length whether introduced by permeabilization or ionophore, in both models, it effects a radial contraction (Ulfendahl, 1987; Dulon et al., 1990). In the intact cell model, elongation is presumed to result from the passive response to increased hydrostatic pressure due to a constant volume constraint that is not present in permeabilized cells (Dulon et al., 1990; Schacht et al., 1995).

The reversibility of the ionophore response and an inhibition by calmodulin antagonists suggest the involvement of calmodulin-dependent mechanisms which include protein phosphorylation (Dulon et al., 1990). Regulation of muscle contractility by phosphorylation of the regulatory myosin light chain is well established (for reviews, see de Lanerolle and Paul, 1991; Sweeney et al., 1993). Protein phosphorylation has also been implicated in the regulation of motility of nonmuscle cells including other sensory receptor cells, for example, teleost photoreceptors (Liepe and Burnside, 1993; Pagh-Roehl et al., 1993).

We have previously described several second messenger-dependent protein kinase activities in the sensory epithelium of the inner ear, including calcium/calmodulin-dependent activity (Coling and Schacht, 1991). Here, we examined the ability of ML-9, a protein kinase inhibitor selective for myosin light chain kinase (Saitoh et al., 1986; Hidaka and Kobayashi, 1992), to inhibit calcium-dependent length change of isolated outer hair cells.

\section{Materials and methods}

\subsection{Reagents}

All reagents were obtained from Sigma Chemical Co., St. Louis, MO, unless otherwise noted.

\subsection{Outer hair cell motility}

Outer hair cells were obtained from pigmented guinea pigs, 250-300 g (Murphy Laboratories, Plainfield, IN). Tissue and dissociated cells were handled in 'HBS' buffer, made from Hanks' balanced salt solution (Gibco-BRL, Gaithersburg, MD) buffered with $5.0 \mathrm{mM}$ $N$-[2-hydroxyethyl]piperazine- $N^{\prime}$-[2-ethanesulfonic acid] (HEPES), consisting of $137.0 \mathrm{mM} \mathrm{NaCl}, 5.4 \mathrm{mM} \mathrm{KCl}$,

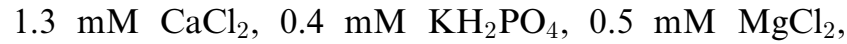
$0.4 \mathrm{mM} \mathrm{MgSO}_{4}, 0.6 \mathrm{mM} \mathrm{Na}_{2} \mathrm{HPO}_{4}, 5.6 \mathrm{mM}$ D-glucose. HBS was adjusted to $\mathrm{pH} 7.40 \pm 0.01$ with $\mathrm{NaOH}$ and to $300 \pm 2$ mOsm with $\mathrm{NaCl}$. All procedures were carried out at room temperature.
Outer hair cells were obtained as previously described (Dulon et al., 1990). Two $60 \mathrm{~mm}$ diameter culture dishes were prepared in advance for the dissociation of cells. A wet paper towel was placed around the periphery of each dish to provide a humid environment to reduce evaporation from small droplets containing tissue or cells. A $50 \mu 1$ droplet of HBS containing 5\% guinea pig serum was placed in the center of each dish. After $10 \mathrm{~min}$, the droplet was replaced with $50 \mu \mathrm{HBS}$ without serum. This treatment reduced adherence of tissue and cells. Eight $60 \mathrm{~mm}$ culture dishes were prepared for imaging cells. A $5 \times 10 \mathrm{~mm}$ oval-shaped hole was cut in the center of each dish and a number 1 glass coverslip was attached to the bottom surface using a silicon grease. Dishes were lined with wet paper towels, as described above, and the wells formed by the holes were filled with $40 \mu \mathrm{l}$ HBS. Culture dishes were placed in a humid box. The precautions to reduce evaporation were effective, as no increases in osmolarity were detected at the end points of experiments. For transfer of tissue and cells, a $50 \mu 1$ Hamilton syringe (Reno, NV) was prepared and handled as follows. The beveled tip of the syringe needle was made blunt and reamed to remove burrs and to provide a bevel on the inner surface of the opening. After shaping the tip, the needle was thoroughly washed with detergent, deionized water, and ethanol. Before each use, the needle was washed with HBS. After each use, the needle was washed with deionized water. The washing procedure is important. In our experience, detergent washes and salt residues from no washing are deleterious to isolated cells.

Stock solutions of $10 \mathrm{mM}$ 1-(5-chloronaphthalene1-sulfonyl)-1 $H$-hexahydro-1,4-diazepine hydrochloride (ML-9, from BioMol Research Laboratories, Inc., Plymouth Meeting, PA) were prepared daily in HBS whose $\mathrm{pH}$ was lowered to 4.0 with $\mathrm{HCl}$. ML-9 was dissolved in dimethylsulfoxide (DMSO) in subsequent experiments (Puschner and Schacht, 1997). Use of this solvent greatly facilitates preparation of solutions. Working solutions $(10 \times$ final concentrations $)$ were made by dilution with HBS pH 7.40 and adjusted to $\mathrm{pH} 7.40$ with $\mathrm{NaOH}$ as required. A control carrier solvent was prepared with identical steps in the absence of ML-9. A $10 \mathrm{mM}$ stock solution of ionomycin (Calbiochem, La Jolla, CA) in DMSO was kept at $4^{\circ} \mathrm{C}$. A working solution of ionomycin, $0.1 \mathrm{mM}, 1 \%$ DMSO in HBS was prepared daily with a working solution of carrier solvent, $1 \%$ DMSO in HBS. All working solutions containing DMSO were adjusted to $300 \pm 2$ mOsm with water prior to application to the cells.

Guinea pigs were anesthetized with $\mathrm{CO}_{2}$ and killed by decapitation. Bullae were removed and opened to expose the bony cochleae on the inner wall of the middle ear. Strips of tissue containing outer hair cells, Hensen's cells and phalangeal processes of Deiters' cells 
were dissected from the apical two and a half turns of cochleae after removal of the stria vascularis and spiral ligament. Tissue strips were transferred to $50 \mu \mathrm{l}$ droplets of HBS in culture dishes prepared for dissociation of cells.

Collection of tissue strips, usually one piece from each cochlea, was completed in 10-15 $\mathrm{min}$ from the time of decapitation. At this time, $50 \mu 11 \mathrm{mg} / \mathrm{ml}$ type IV collagenase was added to the droplet. The tissue was incubated for $15 \mathrm{~min}$ and then washed by transferring it to a $50 \mu \mathrm{l}$ droplet of HBS in a separate dish. Dissociation of outer hair cells occurred upon dispersing the tissue into this droplet. Hensen's cell dissociation was minimal. After a 10 min wash period, 10-15 outer hair cells were transferred to glass coverslips that were prepared as described above. Transfer volumes were typically 3-10 $\mu \mathrm{l}$. Cells were rejected if their shape was not cylindrical and well defined by a sharp birefringence of the plasma membrane, if their cytoplasm was granular, or if their nuclei had ascended from the normal position near the basal aspect (Zajic and Schacht, 1987).

Additions of stock solutions of the protein kinase inhibitor ML-9 or control buffer were made at staggered intervals to provide a $30 \mathrm{~min}$ preincubation period prior to application of calcium ionophore. For dose response determinations, the order of additions of ML-9 or control carrier solvent was shifted daily to minimize the contribution of the metabolic state of the cell as a dependent variable.

After preincubation in protein kinase inhibitor or control buffers, $5 \mu \mathrm{l}$ of a working solution containing either ionomycin (Calbiochem, La Jolla, CA) and DMSO as a carrier, or carrier only was applied to the hair cells maintained in a $45 \mu \mathrm{l}$ droplet for final concentrations of $10 \mu \mathrm{M}$ ionomycin and $0.1 \%$ DMSO as indicated.

Cellular response was recorded for 2 min on a video recorder (Quasar model VH5261, Franklin Park, IL) using a $60 \times$ oil immersion objective on an inverted microscope (Nikon, Melville, NY) fitted with a DAGE Series 68 video camera (Michigan City, IN). Analysis of length change was performed on a digital imaging system (Quantex QX-7-210, Sunnyvale, CA). Cell lengths were measured from the basal pole of the cell to that the apical surface using the birefringence of the plasma membrane for reference. If the membrane appeared to twist or distort in a way that would compromise the measurement, the cell was rejected. Spatial resolution was governed by differences in cell-to-cell response rather than by optical or digital considerations. For 61 cells (initial length $63 \pm 1 \mu \mathrm{m}$ ) stimulated with ionomycin, the variation in cell length was in the order of $\pm 0.1 \mu \mathrm{m}$ (S.E.M.). For 63 control cells challenged with DMSO alone (initial length $64 \pm 1 \mu \mathrm{m}$ ), the variation in cell length was somewhat less. This allowed for adequate resolution for the measurement and statistical analysis of dose responses where cells exhibit intermediate degrees of length change.

\subsection{Calcium measurement}

Changes in intracellular free calcium in response to ionomycin stimulation was measured using the calcium indicator dye, Fluo-3/AM (Molecular Probes, Eugene, OR). Cells were dissociated as described above and loaded with $1 \mu \mathrm{M}$ Fluo-3/AM during the $30 \mathrm{~min}$ incubation period in the presence or absence of the protein kinase inhibitor ML-9. Following loading, cells were washed with HBS with or without ML-9. Details of loading, recording and analysis have been reported previously (Dulon et al., 1990).

\subsection{Cell viability}

Dissociated outer hair cells were assayed for their ability to exclude the entry of propidium iodide through intact membranes (Jones and Senft, 1985) according to previously reported procedures (Dulon et al., 1989).

\subsection{Animal use and care}

The care and use of the animals for this project were approved by the University Committee on Use and Care of Animals, the University of Michigan for NIH program project grant DC-00078 Perception and Processing of Complex Biological Signals. The protocols are in compliance with guidelines of the National Institutes of Health and the Declaration of Helsinki.

\section{Results}

\subsection{Ionophore-induced cell elongation}

Outer hair cell motility may be induced by the calcium ionophores calcimycin (A23187) or ionomycin (Dulon et al., 1990). Here, we applied ionomycin to cells after a $30 \mathrm{~min}$ incubation in the presence or absence of the protein kinase inhibitor ML-9. In the absence of ML-9, cells responded with a significant increase in axial length over the course of $2 \mathrm{~min}$ (Fig. 1, solid squares). Application of the carrier solvent $(0.1 \%$ DMSO) alone had no effect on cell length (Fig. 1 , open squares). Cells were obtained from the apical two and a half turns of the cochlea and ranged in length from 43 to $87 \mu \mathrm{m}$. The response of 96 cells to ionomycin indicated a tendency for percent length change to vary inversely with cell length. However, the experiments were not designed to test this relationship statistically. 

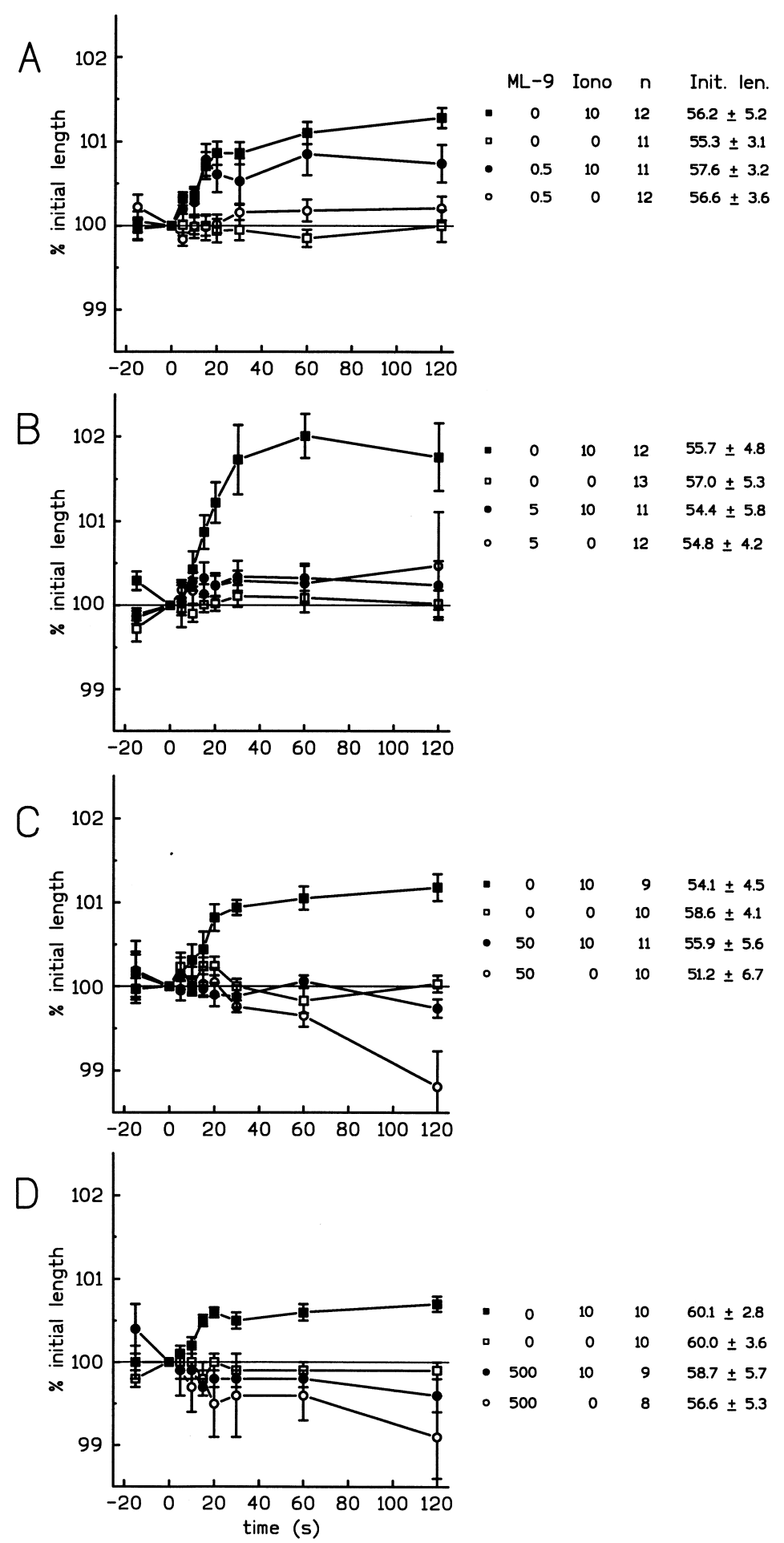

Fig. 1. Time course of calcium ionophore-induced cell elongation. Isolated outer hair cells were incubated for 30 min in either HBS control buffer (solid and open squares) or in HBS containing ML-9 (solid and open circles). ML-9 concentration was (A) $0.5 \mu \mathrm{M}$, (B) $5 \mu \mathrm{M}$, (C) $50 \mu \mathrm{M}$, and (D) $500 \mu \mathrm{M}$. At time 0 , cells were stimulated with $10 \mu \mathrm{M}$ ionomycin, $0.1 \%$ DMSO (solid squares and solid circles) or DMSO alone (open squares and open circles). The length of each cell was measured over a 2 min period as described in Section 2. Percent initial length is plotted as means \pm S.E.M. over a 2 min time period. ML-9 and ionomycin (iono) concentrations (in $\mu \mathrm{M}$ ), numbers of cells (n) and mean initial lengths $( \pm$ S.E.M.) are given in the legends.

\subsection{Effect of $M L-9$ alone on cell length}

After 30 min preincubation in ML-9 alone at 0.5 and
$5 \mu \mathrm{M}$ cell length was stable during the 2 min measurement interval (Fig. 1A,B, open circles). At higher concentrations (50 and $500 \mu \mathrm{M}$, Fig. 1C,D, open circles), 

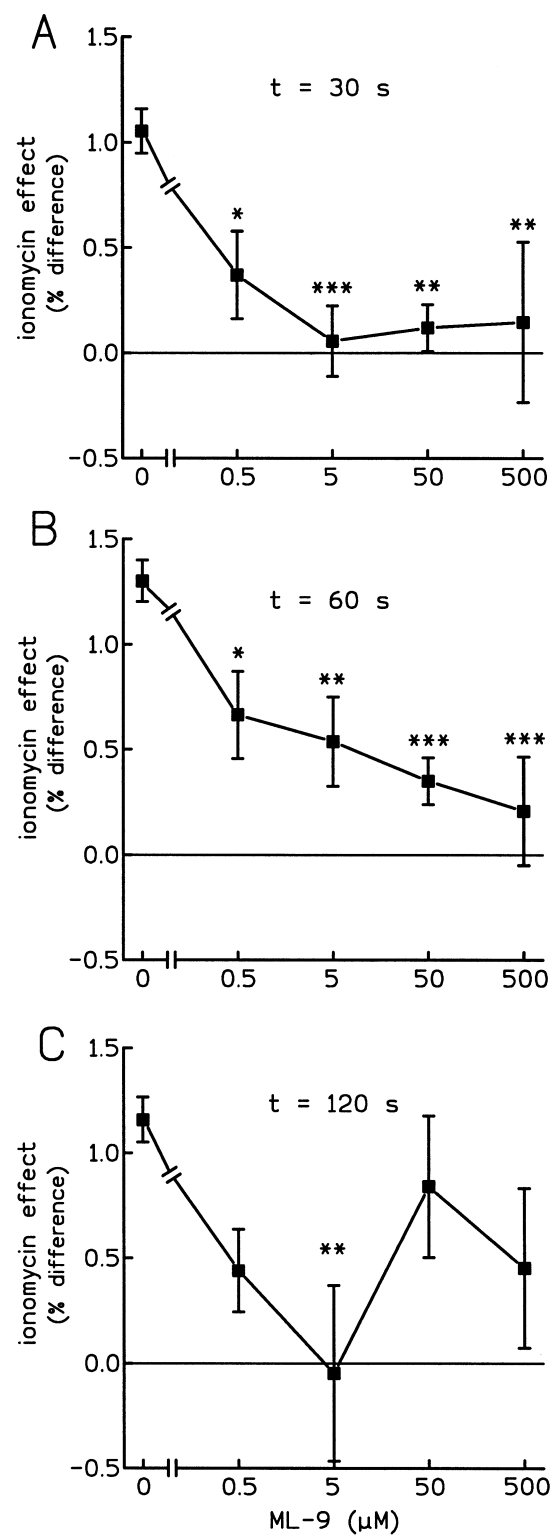

Fig. 2. Dose-dependent inhibition of the ionomycin effect by ML-9. The 'effect of ionomycin' is plotted as a function of ML-9 concentration. Ordinate values give the differences between the mean percent length change of cells treated with or without ionomycin for time points 30 (A), 60 (B), and $120 \mathrm{~s}(\mathrm{C})$ after ionomycin or control buffer application (i.e. the difference between values for solid and open symbols of Fig. 1). Values for $0 \mu \mathrm{M}$ ML-9 were obtained by pooling results for positive controls (solid and open squares of Fig. 1A-D). Error bars are pooled estimators of S.E.M. calculated from the errors of control and experimental conditions. Asterisks indicate significant reductions in the ionomycin effect for a given concentration of ML- 9 compared to no drug $(* P<0.05 ; * * P<0.01$, $* * * P<0.001)$.

however, we observed cells to be in a state of contraction during the measurement interval. Cells treated with $50 \mu \mathrm{M}$ ML-9 for $30 \mathrm{~min}$ shortened at a rate of $0.28 \mu \mathrm{m} /$ min $(P<0.0001$, two-tailed least squares linear regression, Fig. 1C, open circles). Cells treated with $500 \mu \mathrm{M}$ ML-9 for $30 \mathrm{~min}$ shortened at a rate of $0.26 \mu \mathrm{m} / \mathrm{min}$ $(P<0.01$, Fig. 1D, open circles). The effect of this con- traction on the dose response analysis is explained below.

\subsection{Dose dependence and kinetics of inhibition by $M L-9$}

ML-9 was tested as an inhibitor of the ionomycin effect by incubating outer hair cells with varying drug concentrations for $30 \mathrm{~min}$ prior to application of ionomycin. 'Ionomycin effect' (Fig. 2) is defined as the difference in percent of initial length between cells stimulated with ionomycin $(10 \mu \mathrm{M}$ in $0.1 \%$ DMSO $)$ and those stimulated with control buffer $(0.1 \%$ DMSO only). In the context of Fig. 1, we define 'ionomycin effect' as the difference between values for closed symbols and open symbols. This difference was determined at 30,60 and $120 \mathrm{~s}$ after ionomycin or control buffer application (Fig. 2). At each time point, a robust effect, typical of previous experiments, was observed in the absence of ML-9.

Lower concentrations of ML-9 were potent inhibitors of this effect. Inhibition of ionomycin-induced elongation was most pronounced at $30 \mathrm{~s}$ after application of ionomycin. At this time point, pretreatment of cells with $0.5 \mu \mathrm{M}$ ML-9 resulted in a significant reduction of the ionomycin effect while treatment with $5 \mu \mathrm{M}$ and higher concentrations led to a complete block (Fig. 2A). At $60 \mathrm{~s}$ after ionomycin application, pretreatment of cells with ML-9 also resulted in significant reductions in ionomycin-induced motility at all concentrations tested. The ionomycin effect decreased monotonically with increasing ML-9 concentration (Fig. 2B). The

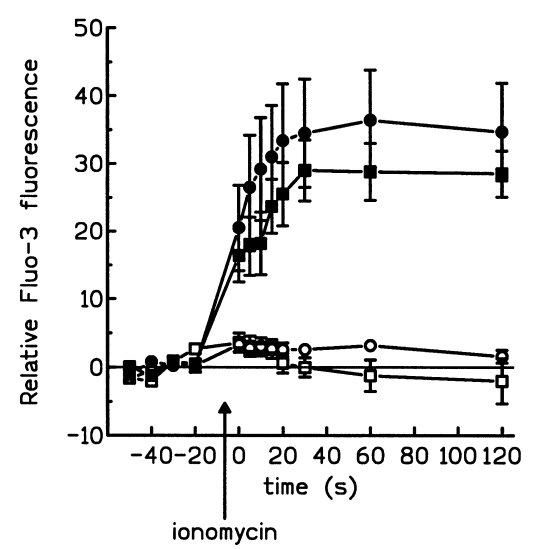

Fig. 3. ML-9 does not impair ionophore-induced calcium entry. Isolated hair cells were loaded with the fluorescent calcium indicator Fluo-3/AM as described in Section 2. Cells were pretreated for 30 min with either $50 \mu \mathrm{M}$ ML-9 (circles) or control buffer (squares) and then treated for $2 \mathrm{~min}$ with either $10 \mu \mathrm{M}$ ionomycin in $0.1 \%$ DMSO (solid symbols) or DMSO alone (open symbols). Relative Fluo-3 fluorescence, as a measure of free intracellular calcium, is plotted as a function of time after ionomycin or DMSO treatment. Data represents the mean \pm S.E.M. for 36 cells with $8-10$ cells per treatment. Symbols for treatments with ML-9 and ionomycin are consistent with those in Fig. 1. 
$\mathrm{EC}_{50}$ of ML-9 at 30 and $60 \mathrm{~s}$ after ionomycin application was approximately $0.3 \mu \mathrm{M}$.

At $120 \mathrm{~s}$ after ionomycin application, the ionomycin effect was reduced using $0.5 \mu \mathrm{M}$ ML-9 and significantly inhibited using $5 \mu \mathrm{M}$. However, at this time point, $50 \mu \mathrm{M}$ and $500 \mu \mathrm{M}$ ML-9 were ineffective at blocking the effect of ionomycin (Fig. 2C). This lack of inhibition resulted from the following responses. Cells pretreated with $50 \mu \mathrm{M}$ ML-9 did not elongate upon application of ionomycin (Fig. 1C, solid circles). They did, however, shorten significantly in control incubations of ML-9 without ionomycin (Fig. 1C, open circles). The resulting difference constitutes an 'ionomycin effect' by our definition (Fig. 2C). Treatment of cells with $500 \mu \mathrm{M}$ ML-9 resulted in a similar responses (Fig. 1D, solid and open circles) and a similar 'ionomycin effect' (Fig. 2C).

\subsection{The locus of ML-9 inhibition is downstream of calcium entry}

The possibility that ML-9 may be acting nonspecifically by blocking calcium entry was tested using the fluorescent calcium indicator, Fluo-3/AM. We observed a rise in Fluo-3 fluorescence on the addition of ionomycin, in agreement with Dulon et al. (1990). Addition of $50 \mu \mathrm{M}$ ML-9 had no effect on the kinetics or magnitude of the ionomycin-induced rise of Fluo-3 fluorescence (solid symbols, Fig. 3) nor on the baseline response in the absence of ionophore (open symbols, Fig. 3).

\subsection{Viability of ML-9-treated hair cells}

To address the possibility that the inhibitory effects of ML-9 may be associated with a general metabolic insult, we used propidium iodide to test the viability of cells incubated in the presence or absence of ML-9 at 5 and $50 \mu \mathrm{M}$. We observed no differences in hair cell viability, measured by the ability to exclude propidium iodide from the nucleus. After $30 \mathrm{~min}$ incubation, $82 \pm 4 \%$ of the cells remained viable in the presence of $50 \mu \mathrm{M}$ ML-9 as compared to $80 \pm 3 \%$ in its absence (mean \pm S.E.M., $n=11$ cells per group). Cells treated with $500 \mu \mathrm{M}$ ML-9 developed a grainy appearance indicative of deterioration.

\section{Discussion}

The experimental results support the hypothesis extended by Dulon et al. (1990) that ionomycin-induced motility of outer hair cells is mediated by protein phosphorylation. Further, they provide information pointing toward potential molecular components of this regulatory system.

\subsection{Biochemical model}

Dulon et al. (1990) reported a circumferential contraction and accompanying longitudinal elongation in intact outer hair cells from guinea pig induced by calcium ionophores. They suggested that this type of hair cell motility involved calcium-dependent protein phosphorylation since it was reversible and completely blocked by calmodulin antagonists. Inhibition with ML-9, reported here, is consistent with the involvement of protein phosphorylation. Moreover, inhibition of slow motility of outer hair cells by ML-9 has been replicated by others (Puschner and Schacht, 1997).

Myosin light chain kinase (MLCK) is a potential target of ML-9 in outer hair cells. The $k_{\mathrm{i}}$ of ML-9 for this enzyme, determined in vitro $(3.8 \mu \mathrm{M}$, Saitoh et al., 1986; Hidaka and Kobayashi, 1992) is comparable to the $\mathrm{EC}_{50}$ (approximately $0.3 \mu \mathrm{M}$ ) for hair cell motility. MLCK activity has been identified in the organ of Corti (Sziklai et al., 1986) and detected by its immunoreactivity in preparations from isolated outer hair cells (Knipper et al., 1995). The enzyme is a member of a large family of calcium/calmodulin-dependent protein kinases (Nairn et al., 1985). Thus, a block of outer hair cell motility by the MLCK inhibitor ML-9 is consistent with both the calcium dependence and the block by calmodulin antagonists observed by Dulon et al. (1990).

These arguments can be taken to support the working hypothesis that calcium-dependent motility of outer hair cells involves the action of an 'MLCK-like enzyme' (as defined by its potent inhibition by ML-9). However, they rely on the assumptions that (1) the principal effect of ML-9 on hair cells is inhibition of a protein kinase, and (2) the relative selectivities of protein kinase inhibitors from in vitro assays extend to intact cells.

Our experiments with Fluo-3 address the first point. ML-9 does not block ionomycin-induced calcium entry into hair cells. This is consistent with an intracellular target for ML-9 downstream of calcium entry. The second point, regarding selectivity of protein kinase inhibitors, cannot be resolved by these experiments. ML-9 has been shown to be more selective for MLCK than for protein kinase A or protein kinase C (Saitoh et al., 1986; Hidaka and Kobayashi, 1992). However, its effects on other calcium/calmodulin-dependent enzymes (such as calmodulin-dependent protein kinase II) have not been documented yet. Thus, while our data are consistent with an involvement of MLCK, there remains the possibility that another protein kinase, calmodulin-dependent protein kinase II, for example, may be the effective target of ML-9 with respect to maintenance of outer hair cell length.

There also remains the possibility that, at high concentrations (50 and $500 \mu \mathrm{M}$ ), ML-9 interacts with multiple targets within the hair cell. This may result in a more complex response and account for the lack of 


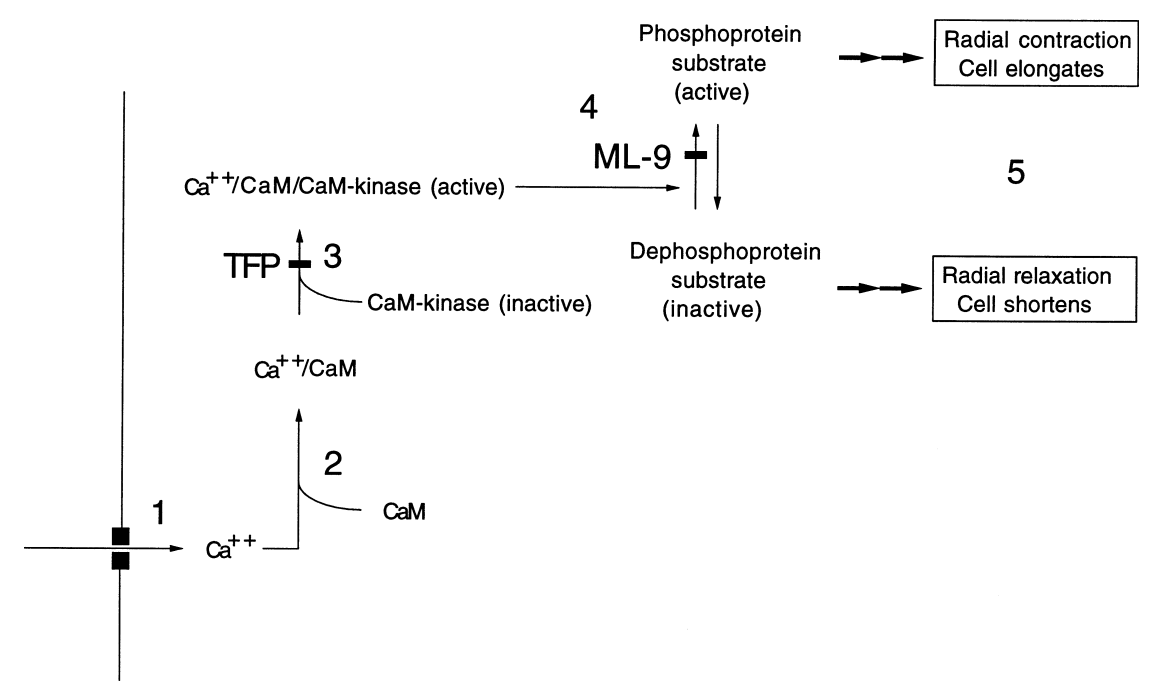

Fig. 4. Working model for calcium-dependent outer hair cell motility. Step 1: elevation of free calcium from mobilization of intracellular calcium stores (reviewed in Wangemann and Schacht, 1996) or from entry of extracellular calcium through plasma membrane channels (reviewed in Kros, 1996) or ionophores. Step 2: formation of calcium/calmodulin complex. Step 3: activation of protein kinase by binding of calcium/calmodulin complex (blocked by trifluoperazine, Dulon et al., 1990). Step 4: activation of protein substrate by phosphorylation (blocked by ML-9). Step 5: initiation and maintenance of cell motility (may include additional steps). Abbreviations: CaM, calmodulin; CaM-kinase, a member of the family of calmodulin-dependent protein kinases; TFP, trifluoperazine.

inhibitory effect for long incubation times $(2 \mathrm{~min}$ in ionomycin).

We propose the following model for the role of protein phosphorylation in the maintenance of cell shape (Fig. 4). We suggest that basal levels of calcium drive a low level of enzymatic activity that maintains the cell in its resting shape (Pou et al., 1991). When the enzyme is activated by elevation of intracellular calcium (steps 13 ), the cell's circumference decreases by active contraction and its length increases passively (steps 4-5). When the enzyme is inhibited or when its substrate is dephosphorylated (step 4), the circumference increases and the cell shortens from internal restoring forces. This system affords hair cells an exquisite active control of cell shape in both low and high calcium states.

The initial steps of this model (steps 1-3) are in agreement with previous experiments (Dulon et al., 1990; Pou et al., 1991). A physiological mechanism for the elevation of cytoplasmic calcium (step 1) has not yet been established. Accordingly, in our working model, calcium elevation in step 1 may be from either extracellular calcium or intracellular stores. The involvement of calmodulin or a similar calcium-binding regulatory protein (steps 2 and 3 ) is consistent with the inhibition of ionophore-induced motility by trifluoperazine (Dulon et al., 1990). Through the use of protein kinase inhibitors, the data in this report and that of Puschner and Schacht (1997) support the involvement of a calcium/calmodulin-dependent protein kinase (step 4) in the mediation of calcium-induced elongation of outer hair cells as predicted by Dulon et al. (1990). In addition, the data in this report on the effects of ML-9 alone suggest that this enzyme functions in the main- tenance of resting cell shape. This aspect of the model is consistent with the hypothesis that intracellular calcium levels regulate resting cell length (Pou et al., 1991).

\subsection{Physiological considerations}

The functional significance of calcium-dependent motility of outer hair cells is not yet established. In this study, we have focused only on events downstream of calcium entry. The calcium levels used, as well as the voltage signals used in most investigations of fast outer hair cell motility, both far exceed physiological parameters near the threshold of hearing. They do, however, serve to establish the maximum displacements that may be achieved in outer hair cells.

Homeostatic mechanisms, like that proposed in our biochemical model, may modulate hearing in either of two ways. First, activation of calcium-dependent motile systems may amplify or attenuate voltage-dependent motile responses or may introduce nonlinearities. This general idea was reviewed by Schacht et al. (1995) and is in agreement with recent measures of the effects of neurotransmitter substances on the mechanical properties of outer hair cells and on electromotility (Sziklai and Dallos, 1993; Housley et al., 1995; Sziklai et al., 1996; Dallos et al., 1997).

Second, modulation of calcium-dependent motile systems in outer hair cells, as well as in supporting cells of the organ of Corti, could lead to changes in geometrical shape or mechanical impedance of the component cells. Such changes could, in turn, modulate the overall mechanical response of the tissue to stimulation by sound, at levels both within the operating range of 
the ear, as well as at more traumatic sound levels. This idea is consistent with the suggestion by Holley (1996) that slow motility may account for some of the morphological correlates of reversible noise trauma.

\subsection{Summary}

The data presented here and elsewhere (Dulon et al., 1990; Pou et al., 1991; Puschner and Schacht, 1997) are consistent with the working hypothesis that outer hair cell shape is under control of a calcium/calmodulindependent protein kinase that is potently inhibited by ML-9. It is anticipated that ML-9 and related reagents, coupled with protein phosphorylation and immunocytochemistry, will be useful in identifying proteins that effect and regulate mechanical properties of outer hair cells. In addition, ML-9 may be a useful tool for physiological investigations of outer hair cell function.

\section{Acknowledgments}

This work was supported by NIH Grant DC-0078 awarded to Dr. Jochen Schacht at the University of Michigan. The authors wish to thank Gary Zajic for his generous technical consultations on outer hair cell isolation and on video microscopy measurements. We also thank Dr. Schacht for his critical advice and his encouragement in every aspect of this project.

\section{References}

Ashmore, J.F., 1987. A fast motile response in guinea-pig outer hair cells: The cellular basis of the cochlear amplifier. J. Physiol. 388, 323-347.

Brownell, W.E., Bader, C.E., Bertrand, D., Ribaupierre, Y., 1985. Evoked mechanical responses of isolated cochlear hair cells. Science 227, 194-196.

Coling, D.E., Schacht, J., 1991. Protein phosphorylation in the organ of Corti: Differential regulation by second messengers between base and apex. Hear. Res. 57, 113-120.

Dallos, P., 1985. Response characteristics of mammalian cochlear hair cells. J. Neurosci. 5, 1591-1608.

Dallos, P., 1992. The active cochlea. J. Neurosci. 12, 4575-4585.

Dallos, P., He, D.Z.Z., Lin, X., Sziklai, I., Mehta, S., Evans, B.N., 1997. Acetylcholine, outer hair cell electromotility, and the cochlear amplifier. J. Neurosci. 17, 2212-2226.

Davis, H., 1983. An active process in cochlear mechanics. Hear. Res. 9, 79-90.

de Lanerolle, P., Paul, R.J., 1991. Myosin phosphorylation/de-phosphorylation and regulation of airway smooth muscle contractility. Am. J. Physiol. 261, L1-14.

Dulon, D., Aran, J.-M., Schacht, J., 1987. Osmotically induced motility of outer hair cells: implications for Meniere's disease. Arch. Otorhinolaryngol. 244, 104-107.

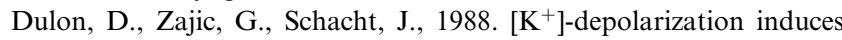
motility in outer hair cells by an osmotic mechanism. Hear. Res. $32,123-130$.

Dulon, D., Zajic, G., Aran, J.-M., Schacht, J., 1989. Aminoglycoside antibiotics impair calcium entry but not viability and motility in isolated cochlear outer hair cells. J. Neurosci. Res. 24, 338-346.

Dulon, D., Zajic, G., Schacht, J., 1990. Increasing intracellular free calcium induces circumferential contractions in isolated cochlear outer hair cells. J. Neurosci. 10, 1388-1397.

Flock, A., Flock, B., Ulfendahl, M., 1986. Mechanisms of movement outer hair cells and a possible structural basis. Arch. Otorhinolaryngol. 1243, 83-90.

Goldstein, A.J., Mizukoshi, O., 1967. Separation of the organ of Corti into its component cells. Ann. Otol. Rhinol. Laryngol. 76, 414427.

Hidaka, H., Kobayashi, R., 1992. Pharmacology of protein kinase inhibitors. Annu. Rev. Pharmacol. Toxicol. 32, 377-397.

Holley, M.C., 1996. Outer hair cell motility. In: Dallos, P., Popper A.N., Fey, R.R. (Eds.), The Cochlea. Springer, New York, pp. 386-434.

Housley, G.D., Connor, B.J., Raybould, N.P., 1995. Purinergic modulation of outer hair cell electromotility. In: Flock, A., Ottoson, D., Ulfendahl, M. (Eds.), Active Hearing. Pergamon, Great Yarmouth, pp. 221-238.

Jones, K.H., Senft, J.A., 1985. An improved method to determine cell viability by simultaneous staining with fluorescein diacetate-propidium iodide. J. Histochem. 33, 77-79.

Kachar, B., Brownell, W.E., Altschuler, R., Fex, J., 1986. Electrokinetic shape changes of cochlear outer hair cells. Nature 322, 365-368.

Knipper, M., Zimmermann, U., Kopschall, I., Rohbock, K., Jungling, S., Zenner, H.P., 1995. Immunological identification of candidate proteins involved in regulating active shape changes of outer hair cells. Hear. Res. 86, 100-110.

Köessl, M., Russell, I.J., 1992. The phase and magnitude of hair cell receptor potentials and frequency tuning in the guinea pig cochlea. J. Neurosci. 12, 1575-1586.

Kros, C.J., 1996. Hair cell physiology. In: Dallos, P., Popper A.N., Fey, R.R. (Eds.), The Cochlea. Springer, New York, pp. 318-385.

Liepe, B.A., Burnside, B., 1993. Cyclic nucleotide regulation of teleost rod photoreceptor inner segment length. J. Gen. Physiol. 102, 7598.

Nairn, A.C., Hemmings, H.C., Greengard, P., 1985. Protein kinases in the brain. Annu. Rev. Biochem. 54, 931-976.

Pagh-Roehl, K., Han, E., Burnside, B., 1993. Identification of cyclic nucleotide-regulated phosphoproteins, including phosphoducin, in motile rod inner-outer segments of teleosts. Exp. Eye Res. 57, 679691.

Pou, A.M., Fallon, M., Winbery, S., Bobbin, R.P., 1991. Lowering extracellular calcium decreases the length of isolated outer hair cells. Hear. Res. 52, 305-311.

Preyer, S., Renz, S., Hemmert, W., Zenner, H.P., Gummer, A.W., 1996. Receptor potentials of outer hair cells isolated from base to apex of the adult guinea-pig cochlea: Implications for cochlear tuning mechanisms. Audit. Neurosci. 2, 145-157.

Puschner, B., Schacht, J., 1997. Calmodulin-dependent protein kinases mediate calcium-induced slow motility of mammalian outer hair cells. Hear. Res. 115, 251-258.

Saitoh, M., Naka, M., Hidaka, H., 1986. The modulatory role of myosin light chain phosphorylation in human platelet activation. Biochem. Biophys. Res. Commun. 140, 280-287.

Schacht, J., Zenner, H.P., 1987. Evidence that phosphoinositides mediate motility in cochlear outer hair cells. Hear. Res. 31, 155-159.

Schacht, J., Fessenden, J.D., Zajic, G., 1995. Slow motility of outer hair cells. In: Flock, A., Ottoson, D., Ulfendahl, M. (Eds.), Active Hearing. Pergamon, Great Yarmouth, pp. 209-220.

Sweeney, H.L., Bowman, B.F., Stull, J.T., 1993. Myosin light chain phosphorylation in vertebrate striated muscle: regulation and function. Am. J. Physiol. 264, C1085-1095.

Sziklai, I., Dallos, P., 1993. Acetylcholine controls the gain of the 
voltage-to-movement converter in isolated outer hair cells. Acta Otolaryngol. 113, 326-329.

Sziklai, I., Kiss, J.G., Ribari, O., 1986. Inhibition of myosin lightchain kinase activity in the organ of Corti by $0.3-5$ kilodalton substances of the otosclerotic perilymph. Arch. Otorhinolaryngol. $243,123-128$

Sziklai, I., He, D.Z.Z., Dallos, P., 1996. Effect of acetylcholine and GABA on the transfer function of electromotility in isolated outer hair cells. Hear. Res. 95, 87-99.

Ulfendahl, M., 1987. Volume and length changes in outer hair cells of the guinea pig after potassium-induced shortening. Arch. Otorhinolaryngol. 254, 237-243.
Wangemann, P., Schacht, J., 1996 Homeostatic mechanisms in the cochlea. In: Dallos, P., Popper, A.N., Fey, R.R. (Eds.), The Cochlea. Springer, New York, pp. 130-185.

Zajic, G., Schacht, J., 1987. Comparison of isolated outer hair cells from five mammalian species. Hear. Res. 26, 249-256.

Zenner, H.P., 1986. Motile responses of outer hair cells. Hear. Res. 22, 83-90.

Zenner, H.P., Zimmermann, U., Schmitt, U., 1985. Reversible contraction of isolated mammalian cochlear hair cells. Hear. Res. 18, $127-133$. 